\title{
The Impact of the Private Sector Participation in the Infrastructure Public Services and the Way Forward in Albania
}

\author{
$\mathrm{PhD}$ Arben Bakllamaja \\ Lecturer, Tirana European University. Economic Faculty \\ E_mail: abakllamaja@gmail.com, Tel: 0689019431
}

\section{Doi:10.5901/mjss.2013.v4n3p219}

\section{Abstract}

The strategy of the government of Albania was to use privatization as a mean to improve the productivity of public companies in various public services, to access investment capital and improve service delivery of high cost that impact the economy; and reduce the fiscal burden of loss-making companies. The international literature indicates that for the countries, which are in the development stage private operators have preferred management and lease contracts as a convenient way to introduce themselves. This does not exclude the concession type contract where there is a regulatory system in place and a credible legal system and corporate low for public companies. In many cases where donors or International Finance Institutions (IFI) have played the main role in promoting the PPP, management and lease contracts have been preferred for Private sector participation (PSP). This would increase the likelihood of the success by giving to the private operator the task of improving the utility's operational efficiency and financial viability, while leaving the public authority in charge of investment financing. The management contracts were used to introduce private participation in water utilities for the first time in the water and sanitation sector in Albania in 2004.In early 2000s there was a high level of optimism about the role of the Private sector participation (PSP) to bring the required changes in some key public services. In the late 2000 s until 2012 this optimism declined rapidly. Privatization activity in the water and sewerage public services as a whole dropped off in the late 2000s in Albania and it seems that the electricity services will follow suit.The conclusion is that, promoting private sector participation now in the infrastructure public services - at least as it has been pursued to date in the water and sanitation sector in Albania - will be received with skepticism. The policy makers and decision makers have to take the ownership, and see it as a challenge to the public sector and local private sector that could bring more important changes, including selection of cities and regions which are prone to this partnership. The hypothesis of the analysis of the effects of the PPP in the infrastructure public services in Albania is that the PPP is not a panacea; it can be useful to the countries if they model is suitable to the country's conditions and there is a workable environment with the public sector, which accept its own responsibilities, and encourage competition.

Keywords: Private sector participation (PSP), water and sanitation and energy sector, key methods of privatization, strategy of $P S P$, alternatives of $P S P$

\section{Introduction}

The government of Albania has embarked on the private sector participation in the key infrastructure public services, such as water and sanitation, electricity, urban solid waste, and alike in the second half of 1990.

The Law No. 7973, "On Concessions and Participation of the Private Sector in Public Services and Infrastructure", in 1995 created the legal basis for the new government policy for the private sector participation (PSP) in infrastructure, including water services' provision. The law endorsed concessions, management contracts, or other agreements for the purposes of water production, treatment, or distribution.

The role of the PSP in the public infrastructure service provision was pronounced in the National Strategy for Social and Economic Development (NSSED) in 2001. ${ }^{1}$

The first strategy on Water and Sanitation embraced the role of the PSP in the sector in $2003 .{ }^{2}$ This was reiterated in the revised strategy in 2011, which confirms the policy of the government to continue with this approach in the future ${ }^{3}$

The privatization in the water and sewerage sector in Albania started in early 2000 and included six water and sewerage public companies in the cities of Elbasan, Durres, Fier, Lezhe, Kavaje and Sarande. Only in Elbasan the

\footnotetext{
${ }^{1}$ National Strategy for Social and Economic Development (NSSED)

2 National Water and Sanitation Strategy 2004, pg.

${ }^{3}$ National Water and Sanitation Strategy 2011, pg.
} 
privatization took the form of concession contract, while in the rest of the cities it was a management contract. All above contracts are closed and now these companies are returned to the public operator.

The PSP experience in the six cities has been assessed by the World Bank, KfW and the Albanian responsible stakeholders. In the past decade, OECD/EAP Task Force ${ }^{4}$ and the World Bank have organized a number of regional policy dialogue meetings on private sector participation. The goals of these meetings were to analyze the experience with private sector participation in the development and operation of water supply and sanitation systems in Eastern Europe, Caucasus, and Central Asia (EECCA) by comparing with good international practices, and guiding principles developed by the OECD, World Bank and other partners. ${ }^{5}$

In developing countries there is now a diverse set of private actors and the debate has moved beyond "public vs. private". It is now about the conditions under which water services can be provided effectively and efficiently, whether by public, private or a combination of players. ${ }^{6}$

This paper takes stock of recent privatization trends and lessons learned. It will review first pros and cons, then at some of the key practical issues. Finally the paper will look at alternatives of the role and extent of private sector participation domestic or international in the water sector, and summarizes emerging issues in corporate governance in the public utilities and privatization going forward.

\section{PSP experience in Central and Eastern European Countries}

As stated in the Regional Meeting in Moscow "International experience confirms that PSP is neither a panacea, nor an ultimate objective in itself. Rather, it can be a useful tool to enhance the efficiency and quality of water services (see OECD (2009) and World Bank/IBRD (2009)). ${ }^{7}$

New forms of PSP have emerged that seek to capitalize better on the respective strengths in the public and the private sector. While concession agreements were seen by many stakeholders in the 1990ies as the most relevant risksharing arrangement, lease contracts and mix-capital arrangements have recently emerged as the preferred option by both partners.

The evidence from the recent literature indicates that new private operators from developing and transition countries have also started entering the market. While some 30 years ago, 3-5 operators, mostly from Europe, made the lion's share of the sector; today, the number of private operators active in WSS has risen and their origin has diversified (they now come also from North Africa, Eastern Europe, Latin America and Russia).

The Regional Meeting in Moscow reiterates an important lesson drown from PSP experience in the countries in EECCA region, countries often forget that though PSP can be a valuable option to improve infrastructure management and service delivery, it requires the development of strong regulatory and oversight mechanisms and should be embedded in a broader sector reform process. ${ }^{8}$

\section{PSP experience in the public infrastructure services in Albania}

In the "Document of Policy Development for the Water Infrastructure Sector in the Republic of Albania", in 1999, the government emphasized PSP as a rapid way to improve service quality and productivity of operations of the utilities.

As an important legal step towards the PSP strategy was the Law on transforming the state owned water supply and sanitation enterprises in to Joint Stock Company with all shares owned by the State ${ }^{10}$.

\footnotetext{
4 In 1993, the Task Force for the Implementation of the Environmental Action Programme for Central and Eastern Europe (EAP Task Force) was created in the framework of the "Environment for Europe" process to support the integration of the environment into the broader process of economic and political reform in transition economies. Its secretariat was established in the OECD Environment Directorate. With the enlargement of the European Union, and since the 1998 Aarhus conference, the EAP Task Force focuses on the countries of Eastern Europe, Caucasus, and Central Asia (EECCA).

5 Proceedings from the Regional Meeting on Private Sector Participation in Water Supply and Sanitation in EECCA, Moscow, Minregion, 28-29 January 2010.

6 5th World Water Forum, Instanbul 17 March 2009

${ }^{7}$ Regional Meeting on Private Sector Participation in Water Supply and Sanitation in EECCA, Moscow, pg.12, January 2010

${ }^{8}$ Regional Meeting on Private Sector Participation in Water Supply and Sanitation in EECCA, Moscow, pg.12, January 2010

${ }^{9}$ Vendim i Këshillit të Ministrave "Aprovimi i Dokumentit të Zhvillimit të Politikës për Sektorin e Infrastrukturës së Ujit në Republikën e Shqipërisë" Nr. 571, dt. 8.12.1999.

10 Ligji Nr. 7926, datë 20. 04. 1995 "Për Transformimit e ndërmarrjeve Shtetërore në Kompani Tregëtare".
} 
The PSP in water and sanitation services was regarded in the first strategy of the sector as one of the key pillars of the strategy to improve the service quality and operation efficiency, and mitigate the fiscal burden of the government in the sector. ${ }^{11}$

Albania has experienced two types of the PSP in the water and sanitation sector, concession and management contract. The concession contract was applied in the watter and sewerage company of Elbasan. This contract was awarded to Berlin Wasser company, with the support by KfW in 2002. KfW has opted as well for management contract in Kavaje. This contract was awarded to AquaMundo in 2003. The World Bank has endorsed the management contract for the PSP in the sector in the utilities of Durres, Fier, Lezhe and Sarande. This contract was awarded to Berlin Wasser International company under the Municipal Water and wastewater Project in 2004.

After 2008 there are not PSP in the water and sanitation sector in the country. The concession contract in Elbasan terminated after two years of the contract signing. It was a complete failure. While, the management contracts endorsed by the World Bank and KfW, were closed as scheduled.

This new experience in the country has been perceived differently by the key actors. The general ex-post feeling in the country is that the PSP in the sector was of little effect. The two international organizations were more holistic in their assessments.

In order to make attractive the sector to the international private companies and bring in Albania these potential companies, the government invested politically. Equally important were policy measures taken to liberalize the water tariffs, setting up a regulatory system and the institution in charge of monitoring and enforcing the new rules and regulations. These measures generated lots of optimism amongst the international companies, there was a political will, a legal framework, and a regulatory system in place. This optimism was shared with government officials at the first place.

This optimism declined rapidly after the closure of all contracts with the private international operators. As a matter of fact, both parties were unhappy in the end. The Berlin Wasser International company approached the government to continue its engagement after the completion of the five year management contract in the four cities, but the high skepticism in the government about their performance was the main barrier to consider the offer and start new negotiations.

The international experience tell us that this is not an isolated phenomenon, there are other cases of failures or poor results of the PSP in a number of countries. Each country tells its story, brings its evidence and gives us what are the lessons learned.

To start with, one of the fundamental questions to get an understanding of this story in Albania is that, who was the main driving force to the PSP in the public infrastructure sector? The answer is the international organizations. The World Bank has assisted the government to reform the sector, design policies and prepare for the first strategy in this transition period in 1990 and 2000. Both the World Bank and KfW have approached the government with advises to start with the implementation of the PSP strategy in the sector.

The truth of the matter is that, all governments in Albania of all specters have embraced in the very beginning of the transition the privatization of the public companies in all sectors, making thus Albania one of the first countries in the region with mass and rapid privatization, after Poland. Therefore, for the international organizations Albania was an ideal country to extend the privatization in the public infrastructure sector, and in very sensitive public services, such as water supply and sanitation, and electricity.

One of the main concerns of the governments over the past two decades of transition has been the high fiscal burden of the sector for the central budget. The sector was facing a massive debts fueled by continuous losses from almost all of the utilities. The government felt the pinch of the financial burden of the sector in the budget and wanted to gradually reduce the public funds flow into the sector, in the form of the operating subsidy. The PSP was deemed as a remedy to confront with this fiscal problem by the international organizations and the government as well.

The poor quality of the water and sanitation services, relatively low access of the population to this public services provision, and rapid urbanization of the main urban areas of the country put high pressure on the government to set this sector in its high priority policy agenda. The experience of international private operators was believed by the government to turn around the poor management and operation of the utilities by public operators (as a legitimacy of the past), and improve fast and substantially the service provision to the required standards and satisfaction of the customers.

All the above were measurable policy analysis and decisions taken by the government to bring the private sector in the management and operation of the water and sanitation utilities.

11 Vendim i Këshillit të Ministrave "Për Miratimin e Strategjisë Kombëtare të Furnizimit me Ujë dhe të Sanitetit", Nr. 76, Dt. 16.10.2003. The first National Water and Sanitation Strategy was prepared with the assistance of the World Bank and approved by the government in 2003. 
What we witness during the implementation of the PSPs in the sector was a decline of the political will to focus properly on and try to find solutions to the main problems that were disturbing seriously the operation and management of the utilities by the private operator. In Elbasan the politicians wanted the concessioner BWI to make all expected improvements and then increase tariffs, without reading the contract that tariffs must be the main funding source of these improvements, along with with the loans received. In other cities central and local politicians were adamant to give the required power, as per the management contract, to the international private operator.

It was quite unexpected that the international private operators became the "foe" of the politicians. By using the private operator as a scapegoat of their failure to establish the required institutional cooperation and collaboration, let alone the required support supports, to solve the problems for the service improvements, the government politicians pursued the wrong path.

On the other hand, the international private operators failed to manage the key stakeholders in the government in the context of the transition period and cultural differences. The "make or break" criteria in making the relationships with the government counterparts workable appeared not to be in the private operator's focus. The stakeholders felt they were left out of the contract implementation.

The PSP in the sector was much affected by the poor governance and institutional capacities in the country. To implant the corporate governance concept in the utilities managed by the international private operators, takes some time, and to the disappointment of the international organizations this was inhibited by the government counterpart institutions. The central government has interfered in the appointment of the utility directors, and in the decision to lay off the redundant staff in compliance with the schedule of the Management Contract in the four cities. Furthermore, the staff of the water companies increased instead of reducing it, as defined in the contract for political reasons. The local authorities did not play well its role to support the international private operators to enforce collection of tariffs from families, local private businesses and local public institutions.

The Decree of the Government has inhibited the international private operators to allow the default customers to continue paying monthly bills, by acknowledging at the same time their liability to the service provider to pay accumulated arrears together with reasonable penalties, as it is the international experience. This has hampered the payment of the tariffs from default domestic customers and therefore the collected revenues. ${ }^{12}$

The expected role of the local government bodies to increase the tariffs each year to gradually reach cost coverage level was not seen during the contract implementation, because of the political sensitivity. The cost recovery tariffs policy did not materialize at the policy makers at the local government level.

The privatization in the water sector in Albania has come across the perception of the people that they cannot be deprived from receiving drinking water no matter what. The legacy of the communist era that, drinking water is almost a free commodity was strongly linked to the obligation of the government to guarantee all public services to the population regardless of the financial effects on the utility.

In Albania the PSP was seen by all consumers as a quick fixer of the utility's problems, which can be explained by the lack of history in PSP in the water and sanitation services in the country. The fallout of their expectation was the inability to look at the roles and responsibilities of the government institutions, as key players. In fact, their responsibilities towards the utilities have not diminished after the utilities were handed over to the private operators.

$\mathrm{MC}$ was like a learning process for the government organizations at central and local levels. The way the relevant organizations expressed their expectations about the improvements of the services in the four cities showed their lack of clarity about the limited role and power of the PO has under the $M C$ to bring the expected changes, which was manifested in a high expectation that the PO will bring quick improvements in service provision.

At the time when the private operators were engaged in the operations of the utilities, the later were not transferred yet to the local government, due to the slow implementation of the decentralization reform in the sector.

The overriding concern of the government has been the fiscal effects of massive debts that the sector face as the utilities continues to run losses in large numbers. This became a very thorny issue in the past months between the government and the CEZ private operator, to the point of confrontation that forced the regulator to remove the license of the private international operator. Was this the only solution and the best one? The deterrence have led time and again to confrontation and renewed poor service delivery.

The reality is that the government simply refused to confront this situation with maturity and rationality. And therefore, the reputation of the country to attract PPP in the public services was put at a high risk.

12 The Decree of the Government at that time did not allow the default customers to pay monthly bills unless they pay in full all accumulated arrears together with very high penalties has hampered the payment of the tariffs from domestic customers and therefore the collected revenues. 


\section{Alternatives of the role and extent of private sector participation domestic or international in the water sector.}

The experience of PSP in the world and in the countries with similar conditions and problems like in Albania indicates that the PSP can take many forms. Having said that Albania has just started with PSP and the strong entrepreneurship that Albanians manifest is the basis to explore more on other forms of private sector participation that fit better the environment. That's why

the government with the assistance of the World Bank took the initiative to look at the domestic private sector role as an alternative to the international private, which paved the way to a comprehensive study conducted by Castalia consulting firm in 2008. ${ }^{13}$

This study targeted eight utilities four of which experienced private operators and for others not. The international consultants consulted with the private businesses and the local authorities to test their appetite for domestic PSP, and explore a variety of options that the traditional methods of PSP can take their shapes in the country's context.

In the below BOX 1 Castalia has proposed a soft concession model

\section{BOX 114}

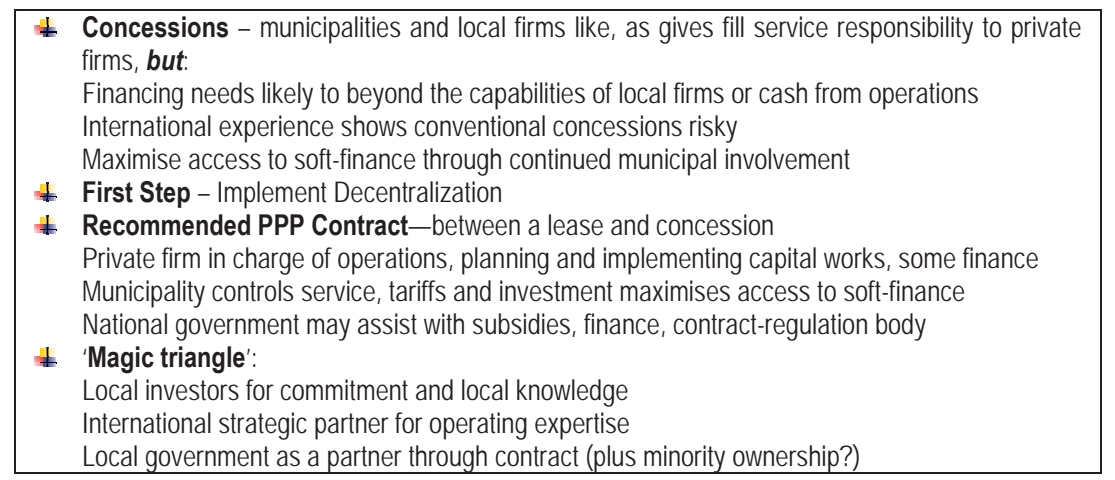

In conclusion, the study came up with a recommended option, which was received well by the government organizations, but no actions were taken further.

Piloting this recommended option would have been very beneficial for all relevant stakeholders that have been involved and showed a good degree of interests. The bottom up approach of developing the model was thought to be the best way to come up with something that brewed in the country and not imported.

\section{Conclusions}

One of the lessons learned in many countries, including Albania, is that, when the public service is a natural monopoly, PPP can embark on serious reform if the private behaviors are regulated and monitored by the regulator of the country. The private behaviors will not be seen as a threat to the public, if the service delivery has been improved to the level of public expectations. This is what is happening with the telephone mobile operators in Albania.

The other important lesson is that, the expected changes in the service delivery cannot be seen quickly in early years after the private operator has taken over the operation of the company. Conditions of the utilities varies a lot, but in many cases those are in poor conditions, physical networks are deteriorated, customers don't pay regularly and therefore it takes time to rehabilitate and renovate the systems, and in particular the customers' behaviors.

Any time the confrontation between the government and the private operator is going to threaten the continuation of the PPP, the international experience tells us that all sides should be taken together to solve the thorny issues and avoid threats or sanctions in the first place. This is the only viable path to resolution.

${ }^{13}$ Castalia Limited, Assessment of Potential for Local Private Sector Participation in Albania Background Documents Report to World Bank, July 2007.

${ }^{14} \mathrm{lbid}$ 
Equally important is to take stock from the experience with PSP in the country, what went wrong and what went right, how the interest of the PO to make profit could be best combined with the interest of the local authorities and citizens in the city for higher access, or better hours of supply, or lower tariffs through improvements of operation efficiency and labor productivity. What capacities do the local authorities have to deal with PSP in water and sanitation services, and how these capacities could be developed.

Continued efforts need to be made to improve the performance of state-owned enterprises by: improving privatization policies and institutions; adopting more of a case-by-case approach for complex sectors and countries; and exposing state enterprises to market discipline by allowing new private entry and exit of unviable state-owned firms and improving their corporate governance.

The current financial and economic crisis presents challenges and opportunities for the water sector. In the face of decreasing revenues, governments might be tempted to reduce public financing of investment in water and sanitation infrastructure. However, the significant economic benefits from investing in the sector suggest that governments have to go further and review the role of PSP in the sector.

\section{References}

Albania National Water Supply and Sewerage Services Sector Strategy 2011-2017, September 2011.

Council of Ministers, "National Strategy for Development and Integration 2002-2013" Tirane Albania.

International Bank for Reconstruction and Development, International Development Association and International Finance Corporation Country Partnership Strategy for Albania for the period FY11-FY14

Proceedings from the Regional Meeting on Private Sector Participation in Water Supply and Sanitation in EECCA, Moscow, Minregion, 28-29 January 2010.

OECD Principles for Private Sector Participation in Infrastructure, OECD 2007

Karl-Ulrich Rudolph And Michael Harbach, Private Sector Participation In water And Sanitation For Developing Countries, CESifo DICE Report 2/2007.

European Commission Directorate-General Regional Policy Guidelines for Successful Public - Private Partnerships, Brussels, February 2003.

World Bank, December 2002 Municipal Water and Wastewater Project, Project Appraisal Document.

Castalia, Strategic Advisors, Assessment of Potential for Local Private Sector Participation in Albania, July 2007.

Albanian legislation on privatization in the water sector. 